\title{
Epitaph for the Handshake
}

We are at one with a man's personality in his handshake.

- G. W. F. Hegel, Aesthetics: Lectures on Fine Art ${ }^{1}$

My body ... discovers in that other body a miraculous prolongation of my own intentions, a familiar way of dealing with the world. Henceforth, as the parts of my body together comprise a system, so my body and the other person's are one whole, two sides of one and the same phenomenon, and the anonymous existence of which my body is the ever-renewed trace henceforth inhabits both bodies simultaneously.

- Maurice Merleau-Ponty, Phenomenology of Perception ${ }^{2}$

By the end of the nineteenth century, the gestures of the Western bourgeoisie were irretrievably lost. . . . In the cinema, a society that has lost its gestures seeks to reappropriate what it has lost while simultaneously recording that loss.

— Giorgio Agamben, "Notes on Gesture" 3

Undamaged experience is produced only in memory, far beyond immediacy. ... Total remembrance is the response to total transience, and hope lies only in the strength to become aware of transience and preserve it in writing.

—Theodor W. Adorno, "On Proust" ${ }^{4}$

In 1979, the two legislative bodies of the State of Connecticut passed into law, without much public attention, a historically decisive initiative. They called it the Home Improvement Act. This act requires all "major" home improvements involving work in return for wages to be preceded by a legally valid contract in some written form. The argument behind the act is compelling: with so many "gentlemen's agreements" broken, so many misunderstandings and abuses, so many cases for litigation, it is entirely reasonable, indeed imperative, that the state insist on the written contract. Its time has come. But the significance of this historical moment should not be missed: it registers the degenerating condition of the body politicand the passing away of old customs, old traditions, bonds forged out of mutual trust and respect, bonds strengthening this trust and respect. For generations of industrious Connecticut Yankees, the neighborly hand- 
shake sealed all verbal agreements, and its traditional interweaving of hands was always thought sufficient to bind all those who took part in the conversation that preceded it. Already too much dishonored, this once beautiful handshake, acknowledging a certain equality, is now still further betrayed, this time by a legislative act that consigns it to the ruins of the past. Felt contact can no longer bind. The time of the verbal contract and its concluding gestures has passed forever. A coldly formal contract has now replaced the warmth of personal contact. Only a few old-timers skilled in the crafts of a passing generation, and a few of their younger apprentices, feel the sadness of this moment and give their politically unheeded voices to the elegy that now needs to be sung.

In Levinas's "In Memory of Alphonse de Waelhens," in which he disagrees with Merleau-Ponty's phenomenological representation of touching hands, the author contemplates the ethical meaning of the handshake, connecting that gesture with a shared experience of trust, and consequently of peace. Essential to the gesture is the "fact" that it involves giving one's hand to the other. Thus Levinas asks: "Is the handshake not, then, an attuning [un s'accorder] of oneself to the other, a giving of oneself?" "The handshake," he says, "is not simply the acknowledgment of an agreement, but, before that confirmation, the extra-ordinary event of peace." 5 Perhaps it will always, therefore, prophetically intimate-without the two parties even knowing it - a certain utopian or messianic dimension of the future.

We need, as Jacques Derrida says in Specters of Marx, "a politics of memory, inheritance, and generation." ${ }^{6}$ This book has been written in remembrance of that vanished handshake, a once great gesture that participated in the moral order as an embodiment of trust and respect. It exists now as little more than a polite greeting, its morally binding function displaced by the legally binding written contract, an instrument of mistrust and coercion.

Is there any hope for what Merleau-Ponty once dreamed of: "an ideal community of embodied subjects, an intercorporeality"? 7 Is there not at work, in the historical memory our gestures never entirely cease to maintain, what Heidegger, in a beautiful phrase, called "the quiet force of the possible"? 8 
GESTURES OF ETHICAL LIFE 
